\title{
Distribution and Characterization of Deep Rhodolith Beds off the Campania Coast (SW Italy, Mediterranean Sea)
}

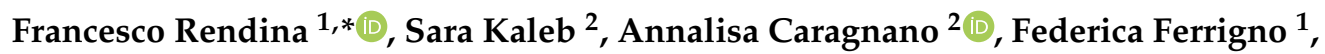 \\ Luca Appolloni ${ }^{1}{ }^{\circledR}$, Luigia Donnarumma ${ }^{1}{ }^{\circledR}$, Giovanni Fulvio Russo ${ }^{1}$, Roberto Sandulli ${ }^{1}(\mathbb{D}$, \\ Valentina Roviello ${ }^{3}$ and Annalisa Falace ${ }^{2}$ D \\ 1 Department of Science and Technology, University of Naples "Parthenope", URL CoNISMa, \\ Centro Direzionale, Is. C4, 80143 Naples, Italy; federica.ferrigno@uniparthenope.it (F.F.); \\ luca.appolloni@uniparthenope.it (L.A.); luigia.donnarumma@uniparthenope.it (L.D.); \\ giovanni.russo@uniparthenope.it (G.F.R.); roberto.sandulli@uniparthenope.it (R.S.) \\ 2 Department of Life Sciences, University of Trieste, Via L. Giorgieri 10, I-34127 Trieste, Italy; \\ skaleb@units.it (S.K.); annalisacaragnano@hotmail.com (A.C.); falace@units.it (A.F.) \\ 3 Department of Chemical, Materials and Production Engineering, University of Naples "Federico II", \\ Piazzale Tecchio 80, 80125 Naples, Italy; valentina.roviello@gmail.com \\ * Correspondence: francesco.rendina@uniparthenope.it
}

Received: 26 June 2020; Accepted: 31 July 2020; Published: 4 August 2020

\begin{abstract}
Rhodolith beds (RBs) are bioconstructions characterized by coralline algae, which provide habitat for several associated species. Mediterranean RBs are usually located in the mesophotic zone (below $40 \mathrm{~m}$ ), and thus are frequently remote and unexplored. Recently, the importance and vulnerability of these habitats have been recognized by the European Community and more attention has been drawn to their investigation and conservation. This study reports the results of an extensive monitoring program, carried out within the Marine Strategy Framework Directive (2008/56/EC), in six sites off the Campania coast (Italy, Mediterranean Sea). New insights were given into the distribution, cover, vitality (i.e., live/dead rhodolith ratio), structural complexity, and coralline algae composition of RBs. Remotely operated vehicles (ROV) investigations allowed the description of several RBs, and the discovery of a RB with rhodolith cover $>65 \%$ offshore the Capri Island. Only two sites (Secchitiello and Punta Campanella) showed a very low mean cover of live rhodoliths $(<10 \%)$; hence, not being classifiable as RBs. The collected rhodoliths were mostly small pralines $(\sim 2 \mathrm{~cm})$, spheroidal to ellipsoidal, with growth-forms ranging from encrusting/warty to fruticose/lumpy. Coralline algae identification revealed a high diversity within each bed, with a total of 13 identified taxa. The genus Lithothamnion dominated all sites, and Phymatolithon calcareum and Lithothamnion corallioides, protected by the Habitats Directive (92/43/EEC), were detected in all RBs.
\end{abstract}

Keywords: rhodolith beds; coralline algae; maerl; ROV; biogenic habitats; Tyrrhenian Sea

\section{Introduction}

Rhodolith beds (RBs) are biogenic habitats formed by unattached, non-geniculate coralline algae (CA; Corallinophycidae, Rhodophyta) [1]. Rhodolith sizes range from 1 to $10 \mathrm{~cm}$, varying from highly branched to roundish shapes [2-4]. These habitats have a worldwide distribution, having been described in tropical [5-7], temperate [8-11], and polar [12-14] regions, from the low intertidal zone to depths over $150 \mathrm{~m}[4,15]$.

RBs are ecosystem engineers, which create 3D biogenic habitats [1] for epiphytes and benthic invertebrates (both epifauna and infauna) [16-18], supporting higher species richness than nearby 
sedimentary habitats $[3,4,19,20]$. They provide critical ecosystem services, being settlement sites and nursery grounds for species of commercial interest [4,21]. In some rare cases, RBs are exploited through direct extraction for soil improvement [22] or may undergo indirect extraction as relict sand for beach nourishment by dredging [23]. RBs are also relevant in climate regulation, through their role in $\mathrm{CO}_{2}$ uptake, primary production, and carbonate production [1,24]. Moreover, through their $\mathrm{CaCO}_{3}$ production and dissolution, they contribute to the carbonate cycle of continental shelf ecosystems $[6,25]$.

RBs are threatened by habitat degradation and loss of structural heterogeneity due to anthropogenic impacts, which can hamper the functioning of these habitats [26]. Rhodoliths are often fragile (particularly unattached branches), and their growth rate is on the order of $1 \mathrm{~mm}$ year ${ }^{-1}$, also depending on environmental factors as light and temperature [4,24,27]. For these reasons, RBs are highly affected by mechanical damage due to extraction of calcareous sediments and bottom fisheries [28-31]. Fish farms and aquaculture can threat these habitats too, by enhancing sedimentation rates and water turbidity [32,33]. Finally, CA, and consequentially RBs, are likely to be negatively affected by both ocean warming and acidification [24,34-36].

RBs have been classified as a non-renewable resource [1,37-39], and their vulnerability has been recognized worldwide though the adoption of several protection instruments. The Habitats Directive (92/43/EEC) [40] included the two species, Phymatolithon calcareum (Pallas) W.H.Adey and D.L.McKibbin ex Woelkering and L.M.Irvine and Lithothamnion corallioides (P.Crouan and H.Crouan) P.Crouan and H.Crouan, among those species subjected to exploitation and for which Member States have to ensure effective conservation measures. Mediterranean RBs have been recently included among the habitats of special interest within the Marine Strategy Framework Directive (MSFD,-2008/56/EC) [41,42], aiming at achieving the "Good Environmental Status" (GES) of all marine waters by 2020. Thus, the assessment of RBs distribution and biodiversity has been included within the protocol to evaluate the GES [1].

In the Mediterranean Sea, RBs, together with Posidonia meadows, coralligenous and vermetid bioconstructions, are considered as marine benthic habitats of high conservation interest and hotspots of biodiversity [43-55]. They are typically found around islands and capes, on submarine plateaux, seamounts, marine terraces, channels and banks [9,53], and frequently occur in the mesophotic zone, mostly at about 30-75 m depth [4], with the deepest bed discovered on the top of a seamount in the Balearic Sea ( 150 m) [15]. They rarely occur at shallower depths, as for Atlantic RBs [1,53].

The current knowledge of their geographic distribution is still fragmented and incomplete, resulting in a wide but patchy distribution along the Mediterranean coasts [53]. This lack of information is due to the remoteness of these habitats, and consequently to expensive and time-consuming sampling efforts [1,56]. Remotely operated vehicles (ROVs) are fundamental instruments currently employed to explore and monitor deep habitats, with non-destructive and standardized protocols [57-61], or to evaluate the impact of fishing activities in coastal ecosystems [62-64]. ROV video/image analyses have been included in the monitoring protocol of RBs within the MSFD, in order to obtain useful data on the RB distribution and status [1]. Nevertheless, this method does not provide reliable information on RB coralline species compositions [1].

Mediterranean RBs are characterized by a higher CA biodiversity than NE Atlantic beds, which are usually monospecific/oligospecific, and mainly composed by Phymatolithon calcareum and Lithothamnion corallioides $[53,65]$. Moreover, RBs can be structured by a suite of combinations of rhodolith shapes and growth-forms [1,53], depending on the species, sedimentation, hydrodynamism, and seabed morphology $[8,66,67]$, concurring to increase the RB complexity, which in turn influences the diversity and abundance of associated assemblages $[3,19,68]$.

This study reports the results of an extensive regional-scale monitoring program, carried out within the MSDF, to provide new insights into the distribution, ecological status, and CA composition of deep Mediterranean RBs occurring off the Campania coast (Italy). 


\section{Materials and Methods}

\subsection{Study Area}

Surveys were carried out in 2017 and 2018, at depths ranging from 42 to $78 \mathrm{~m}$, in six sites off the Campania coast (SW Italy, Mediterranean Sea), within the Italian monitoring program of the MSFD. Sites were chosen based both on previous records of coralline algal deposits along the Campania coast [69-72], and on the empirical knowledge of fishermen. Moreover, morpho-bathymetric data (multibeam echosounder and side-scan sonar) were used to corroborate the sites selection. Four sites were selected within the Gulf of Naples: Capri, Punta Campanella, Secchitiello, and Ischia; and two sites off the Cilento coast: Acciaroli A and Acciaroli B (Figure 1, Table 1).
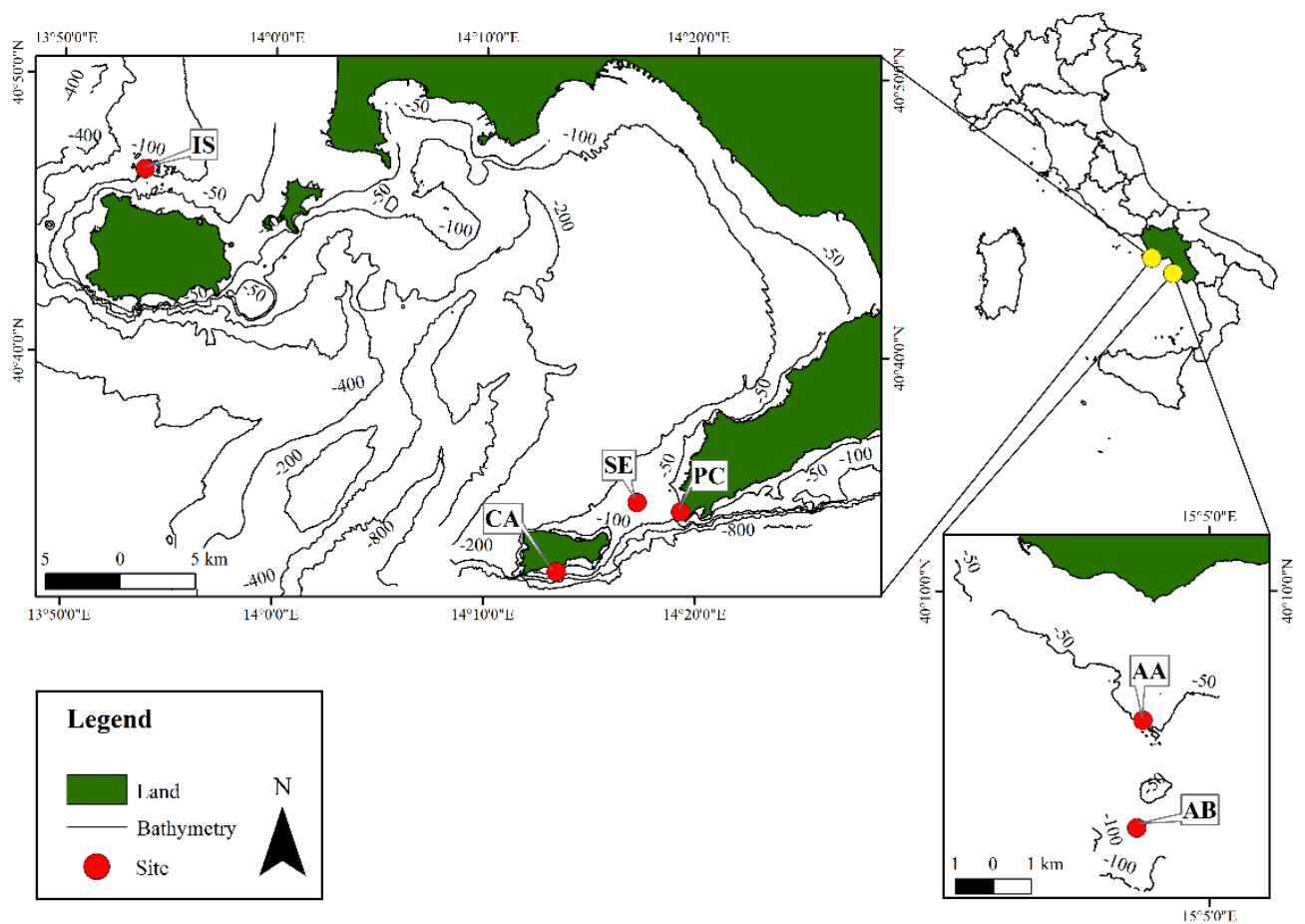

Figure 1. Map of the investigated sites along the Campania coast (Tyrrhenian Sea, Italy). Gulf of Naples' sites: Capri (CA), Punta Campanella (PC), Secchitiello (SE), and Ischia (IS). Cilento coast' sites: Acciaroli A (AA) and B (AB).

Table 1. Resuming data of sampling sites.

\begin{tabular}{cccccc}
\hline Site & Latitude & Longitude & $\begin{array}{c}\text { Time } \\
\text { Period }\end{array}$ & $\begin{array}{c}\text { ROV } \\
\text { Routes' } \\
\text { Depth }\end{array}$ & $\begin{array}{c}\text { Grab } \\
\text { Samples' } \\
\text { Depth }\end{array}$ \\
\hline Capri (CA) & $40^{\circ} 32^{\prime} 20.545^{\prime \prime} \mathrm{N}$ & $14^{\circ} 13^{\prime} 17.653^{\prime \prime} \mathrm{E}$ & Jul-18 & $42-64 \mathrm{~m}$ & $55-59 \mathrm{~m}$ \\
Punta Campanella (PC) & $40^{\circ} 34^{\prime} 26.08^{\prime \prime} \mathrm{N}$ & $14^{\circ} 19^{\prime} 19.049^{\prime \prime} \mathrm{E}$ & $\mathrm{Jul}-18$ & $53-62 \mathrm{~m}$ & $52-62 \mathrm{~m}$ \\
Secchitiello (SE) & $40^{\circ} 34^{\prime} 45.538^{\prime \prime} \mathrm{N}$ & $14^{\circ} 17^{\prime} 15.261^{\prime \prime} \mathrm{E}$ & Aug-18 & $70-78 \mathrm{~m}$ & $68-72 \mathrm{~m}$ \\
Ischia (IS) & $40^{\circ} 46^{\prime} 34.774^{\prime \prime} \mathrm{N}$ & $13^{\circ} 53^{\prime} 49.401^{\prime \prime} \mathrm{E}$ & Apr-17 & $58-73 \mathrm{~m}$ & $62-72 \mathrm{~m}$ \\
Acciaroli A (AA) & $40^{\circ} 8^{\prime} 9.582^{\prime \prime} \mathrm{N}$ & $15^{\circ} 3^{\prime} 46.011^{\prime \prime} \mathrm{E}$ & Jul-17 & $49-52 \mathrm{~m}$ & $48-49 \mathrm{~m}$ \\
Acciaroli B (AB) & $40^{\circ} 6^{\prime} 37.685^{\prime \prime} \mathrm{N}$ & $15^{\circ} 3^{\prime} 39.149^{\prime \prime} \mathrm{E}$ & Jul-17 & $65-73 \mathrm{~m}$ & $62-65 \mathrm{~m}$ \\
\hline
\end{tabular}

\subsection{Remote Data Acquisition and Analysis}

Seafloor data were collected both by a Reson Sea Bat 8125 Multi-Beam Echo-Sounder (MBES) and a Side-Scan Sonar (SSS) Klein 3900 dual frequency system $(100 / 500 \mathrm{kHz})$, which provided imagery with a high level of seabed resolution (100\% coverage possible). SSS images were used to evaluate a possible extent of the rhodolith deposits on the base of sediment texture [73,74]. In fact, SSS backscatter is 
shadowed according to a grey scale of pixels. Each shade corresponds to a combination of RGBA colour (i.e., black: 0,0,0,255; white: 255,255,255,255), which is in turn associated to a colour index, varying from 0 (black, highest backscatter signal) to 150 (white, lowest backscatter signal). Comparing SSS with ROV images and direct samples of seabed, rhodolith deposits resulted to be associated to colour indices ranging between 0 and 90 (Figure 2). Pixels within this colour index range were automatically selected. The analysis was carried out using ArcGis 10.7.1 software.

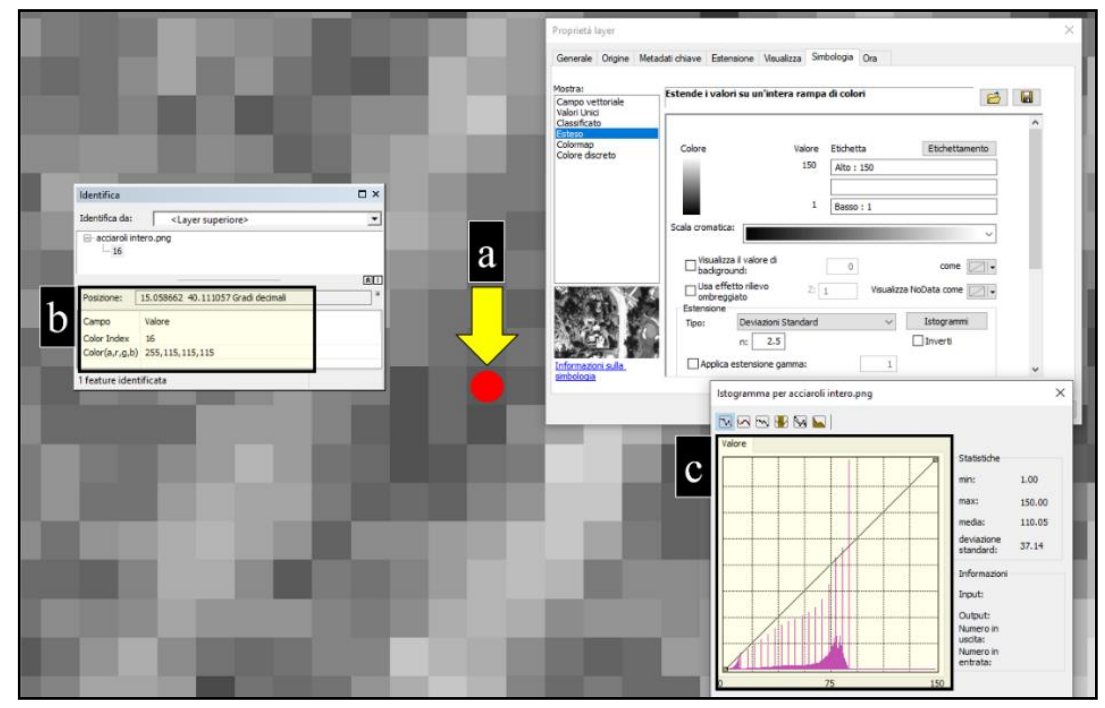

Figure 2. Example of rhodolith deposits definition by ArcGis 10.7.1 software (Acciaroli B site): (a) ROV point on backscatter pixel. (b) Colour index and associated RGBA. (c) Frequency histograms of pixels' colour index in the side-scan sonar (SSS) image (frequencies range from 0 to 90).

Seabed videos were made through a ROV ("Perseus" of Ageotec) equipped with a high definition video camera (DVS-3000 high definition), two lights, two parallel laser beams at the fixed distance of $14.5 \mathrm{~cm}$ for the evaluation of the image surface. The ROV also hosted a navigation camera with underwater positioning system USBL (Ultra Short Base Line System), interfaced with the on-board navigation system, which allows to determine the real time geographical position and the ROV depth. Moreover, in order to estimate potential changes in time within the same area, reconstruction of the ROV routes was performed with the aim of being replicated in future monitoring programs.

At each site, three ROV video-routes were carried out, with a length of ca. $200 \mathrm{~m}$ each and a distance of at least $50 \mathrm{~m}$ from each other, covering a surface of ca. $1800 \mathrm{~m}^{2}$, calculated from the ROV routes' length and the ROV camera field of vision $($ ca. $0.5 \mathrm{~m})$. ROV videos were displayed using the software VisualSoft ${ }^{\circledR}$, allowing the vision of HD videos with overlay of navigation data. A visual assessment of the sea bottom, characterized by rhodolith occurrence, was carried out on 60 images for site, for a total of 360 video frames analysed. The video frames were obtained extrapolating images (each $10 \mathrm{~s}$ ) from the video tracks using the software DVDVideoSoft ${ }^{\circledR}$. Videos' and photos' analyses were carried out according to the monitoring protocol for deep Mediterranean RBs, developed within the MSFD [75]. In particular, the total percentage cover (both live and dead thalli), the vitality (i.e., live vs. dead ratio [76]), and the predominant morphotypes (i.e., pralines, boxwork rhodoliths, and unattached branches [10]) of rhodoliths were analysed. The total (live and dead thalli) percentage cover is a more complete data with respect to the only live thalli cover (considered by MSFD protocol [75]), which does not allow to evaluate the eventual presence of RBs characterized by only dead thalli. Of course, the live thalli cover can be easily calculated by our data, since the live/dead rhodolith ratio was also reported.

In order to carry out bathymetric analyses, video frames from each site were divided into two depth intervals: "shallow", within 40 and 59 m, and "deep", within 60 and 79 m, while to test whether 
there was a significant effect of bottom sediment type on rhodolith cover and vitality, video frames were divided into two main categories: "fine" and "coarse" sediments (Table 2). The influence of depth and sediment on rhodolith cover and live/dead rhodolith ratio was assessed using univariate techniques. Data, checked with the Shapiro-Wilk's test, were not normally distributed; thus, non-parametric tests were applied. Specifically, univariate PERMANOVAs based on similarity matrixes computed using Euclidean distances $[77,78]$ were applied to avoid any assumption about the distribution of the variables [79]. Pairwise tests were run to estimate differences between pairs of sites. Analyses were performed using PAST software for Windows, version 3.16 [80]. Results are expressed as mean \pm standard deviation (SD), and $p$ is the significance.

Table 2. Summary of prevalent ( $>75 \%$ of analysed video frames) depth interval and substrate type at the different sites. "shallow", 40-59 m; "deep", 60-79 m.

\begin{tabular}{ccc}
\hline Site & Depth Interval & Substrate Type \\
\hline Capri (CA) & Shallow & Coarse \\
Punta Campanella (PC) & Shallow & Coarse \\
Secchitiello (SE) & Deep & Fine \\
Ischia (IS) & Deep & Fine \\
Acciaroli A (AA) & Shallow & Coarse \\
Acciaroli B (AB) & Deep & Fine \\
\hline
\end{tabular}

\subsection{Collection and Morphological Characterization of Rhodoliths}

Three random samples were collected using a 251 Van-Veen grab within each site, in the spots detected via ROV characterized by the highest rhodolith cover. Collected rhodoliths were cleaned to remove sediment and epiphytic organisms, air dried for at least $48 \mathrm{~h}$ and stored in the dark in zipper bags with silica gel.

Rhodoliths were classified following MSFD protocol [75] in pralines, boxwork rhodoliths, and unattached branches morphotypes. Results on rhodolith morphology were then plotted in a ternary diagram using the software Origin.

Rhodolith shapes were obtained by measuring the long (L), intermediate (I), and short (S) axes [81]. This provided data for plotting shapes on Sneed and Folk's pebble shape diagram [82]. Finally, the rhodolith size was calculated using the volume of an ellipsoid [8], and data were reported in box plots using Origin software.

\subsection{Coralline Algal Identification}

A preliminary sorting of the CA samples was carried out at the stereomicroscope. Taxonomic identifications were carried out by scanning electron microscope SEM (Nova NanoSem 450-FEI-Thermo Fisher, Scientific, Waltham, MA, USA), following [83]. The identification of non-geniculate red algae follows the specialized literature and algal taxonomy follows Algaebase ([84] and references therein).

After the sorting, each sample was disposed on a $35 \times 35 \mathrm{~cm}^{2}$ square, and then photographed to obtain high resolution images. For each square/image, the percentage cover of each taxon was estimated by the image analysis software VidAna 1.0 [85].

\section{Results}

\subsection{Remote Data}

Rhodolith deposits were found at all the investigated sites, although their cover varied among sites. SSS data, together with ROV data and direct seabed samples, allowed the evaluation of the areal extension of each rhodolith deposit (Figure 3). The wider investigated deposit was the one off the Cilento coast, covering an area of ca. $8.49 \mathrm{~km}^{2}$, where the two sites Acciaroli A and B are present 
(Figure 3e). It was followed by Secchitiello (ca. $0.37 \mathrm{~km}^{2}$; Figure 3b), Capri (ca. $0.13 \mathrm{~km}^{2}$; Figure 3d), Ischia (ca. $0.11 \mathrm{~km}^{2}$; Figure 3a), and Punta Campanella (ca. $0.03 \mathrm{~km}^{2}$; Figure 3c).
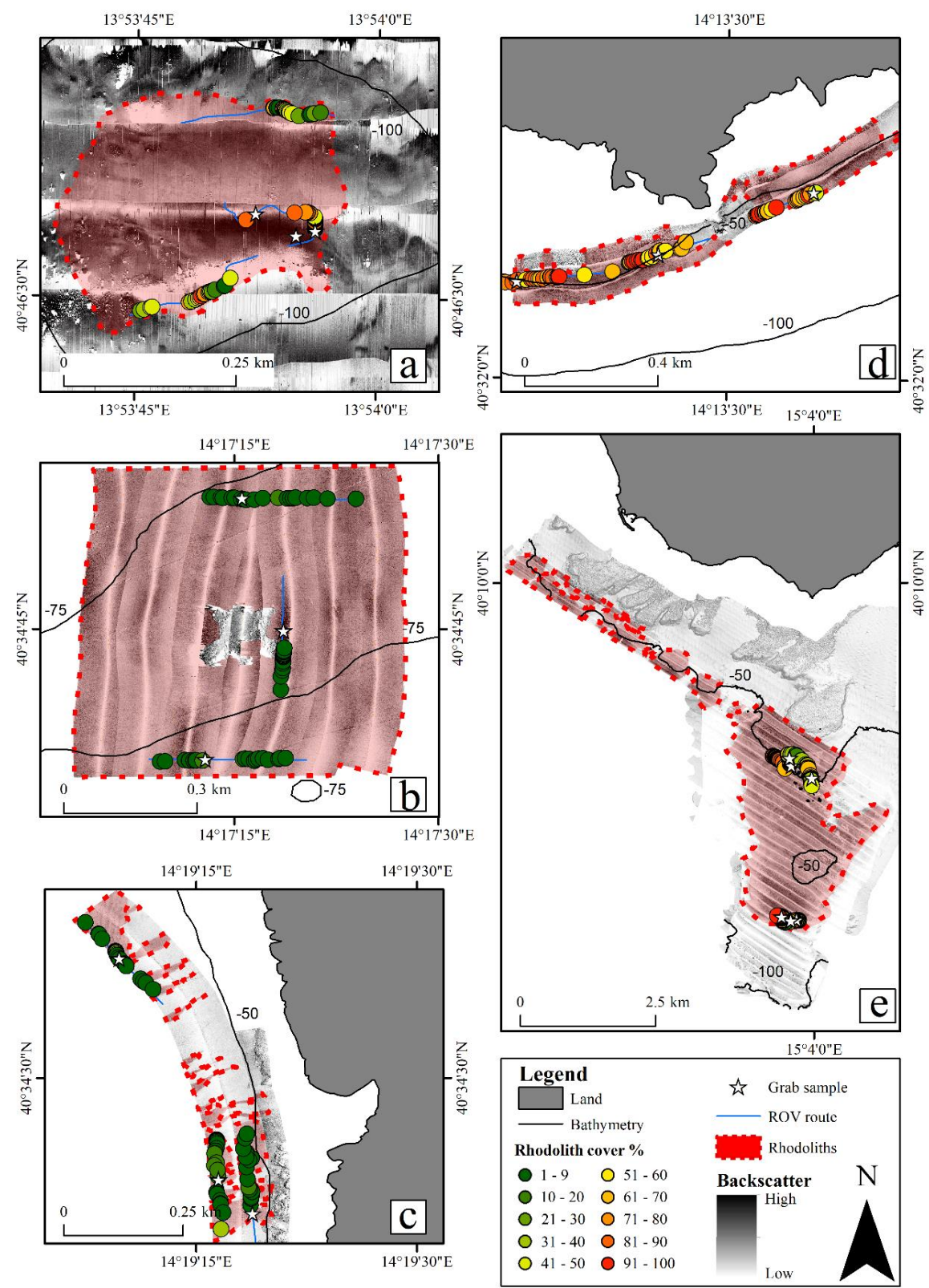

Figure 3. Side-scan sonar images overlaid with maps for the sites of Ischia (a), Secchitiello (b), Punta Campanella (c), Capri (d), and Acciaroli A and B (e), showing a possible extension of the rhodolith deposits. Red polygons localize the rhodolith deposits. Dotted lines mean that the rhodolith deposits could be wider with respect to the established boundaries. Blue lines and white stars indicate ROV routes and grab sampling points, respectively. Coloured dots indicate the total (live and dead) rhodolith cover (\%) of each ROV video frame.

Depth significantly affected rhodolith cover (PERMANOVA, $p<0.001$ ), with higher cover values detected in shallower waters (40-59 m). Likewise, cover was significantly influenced by sediment typologies (PERMANOVA, $p<0.001$ ), with higher values in concurrence with coarse sediment. Significant differences in terms of rhodolith cover were also found among sites (PERMANOVA, $p<0.001$ ). Video frames showed that the two shallower sites (i.e., Capri and Acciaroli A; Table 1) were characterized by the highest mean rhodolith cover (66 \pm 14 and $60 \pm 4 \%$, respectively; Figure 4, 
Figure 5a). Punta Campanella and Secchitiello showed mean rhodolith cover lower than $10 \%(5 \pm 28$ and $2 \pm 21 \%$, respectively). Intermediate cover values were registered at Ischia and Acciaroli B (47 \pm 27 and $40 \pm 10 \%$, respectively).
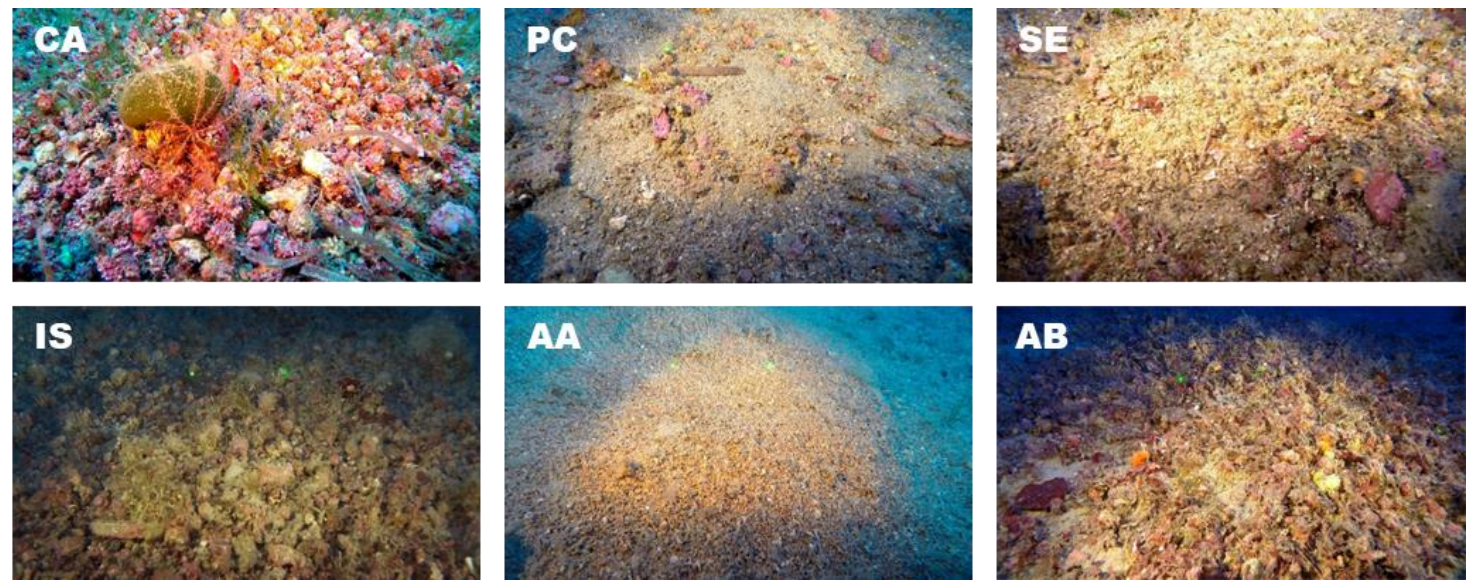

Figure 4. Representative video frames of the explored sites. In each video frame, the 2 green parallel laser beams indicate a fixed distance of $14.5 \mathrm{~cm}$. CA, Capri; PC, Punta Campanella; SE, Secchitiello; IS, Ischia; AA, Acciaroli A; AB, Acciaroli B.

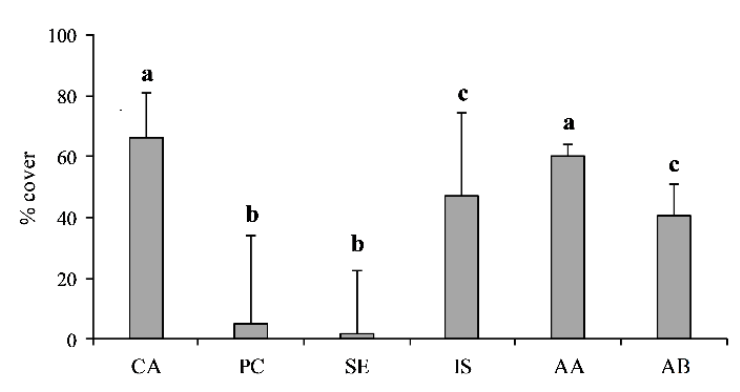

b

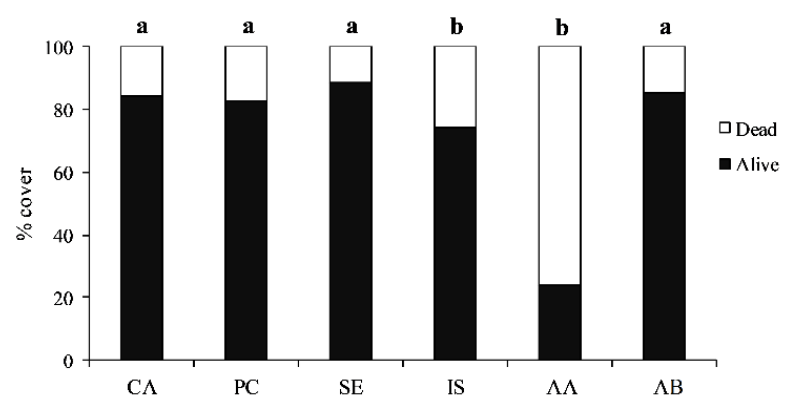

Figure 5. (a) Percentage of total (live and dead) rhodolith cover ( \pm SD) at the investigated sites. (b) Percentage of live vs. dead thalli at each site. CA, Capri; PC, Punta Campanella; SE, Secchitiello; IS, Ischia; AA, Acciaroli A; AB, Acciaroli B. Different letters (a, b, and c) indicate significant differences between sites.

No significant difference in live/dead rhodolith ratio was detected between the two depth intervals and the two substrate types considered (PERMANOVA, $p=0.163$ and 0.156 , respectively). Significant differences in terms of live/dead rhodolith ratio were found among the explored sites (PERMANOVA, $p<0.001$ ). In particular, the lowest percentages of dead thalli were observed at Capri $(16 \pm 8 \%)$, Punta Campanella (17 $\pm 12 \%)$, Secchitiello (12 $\pm 17 \%)$, and Acciaroli B $(14 \pm 9 \%)$ sites; the highest percentages of dead thalli were detected at Ischia and Acciaroli A sites $(26 \pm 15$ and $76 \pm 8 \%$, respectively; Figure 5b).

ROV data showed that pralines were the prevalent morphotype characterizing Capri, Punta Campanella, Secchitiello, and Acciaroli B. At Ischia, the prevalent morphotype was pralines in $73 \%$ of the analysed video frames, while boxwork rhodoliths were the most abundant morphotype in the remaining $27 \%$ of frames. Finally, Acciaroli A was characterized by a prevalence of unattached branches in all the video frames. 


\subsection{Rhodolith Morphology}

Rhodolith growth forms varied from fruticose/lumpy to warty and encrusting (Figure 6a). Pralines were the predominant morphotype within all sites (except Acciaroli A) (Figure 6b), confirming the observations acquired by the ROV. In detail, this morphotype was the only found in all the samples collected at Punta Campanella and Secchitiello. Capri was mostly characterized by pralines too, even if few unattached branches $(<5 \%)$ were also collected in one of the three samples. Ischia was the only site where multi-specific boxwork rhodoliths were collected, although the prevalent morphotype was pralines ( $>70 \%$ in all samples), followed by boxwork rhodoliths and unattached branches. Finally, Acciaroli A was characterized by the dominance of fragmented $(0.6-10 \mathrm{~mm}$ length and $0.2-0.3 \mathrm{~mm}$ diameter) and brownish unattached branches ( $>70 \%$ in all samples), followed by pralines; Acciaroli B was primarily composed by pralines ( $>84 \%$ in all samples), and then by unattached branches.

The sphericity diagram showed a majority of ellipsoidal to spheroidal shapes for all sites (Figure 6c). The mean rhodolith size was relatively small in all sites, ranging from $21.8 \mathrm{~mm} \pm 8.5$ in Capri to $10.6 \mathrm{~mm} \pm 6.1$ in Secchitiello (Figure 6d).

a

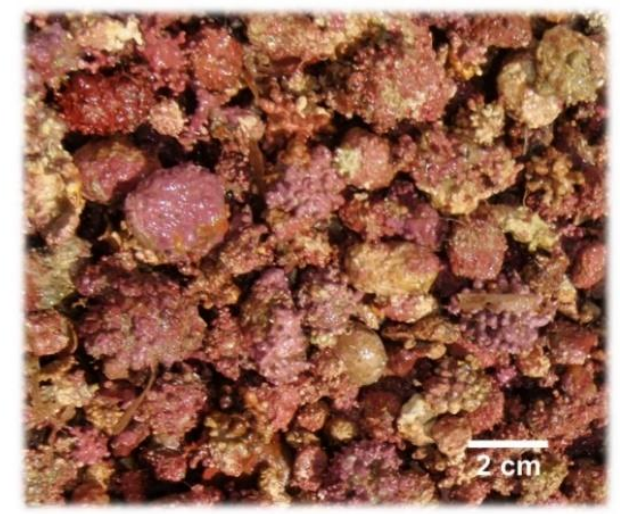

c

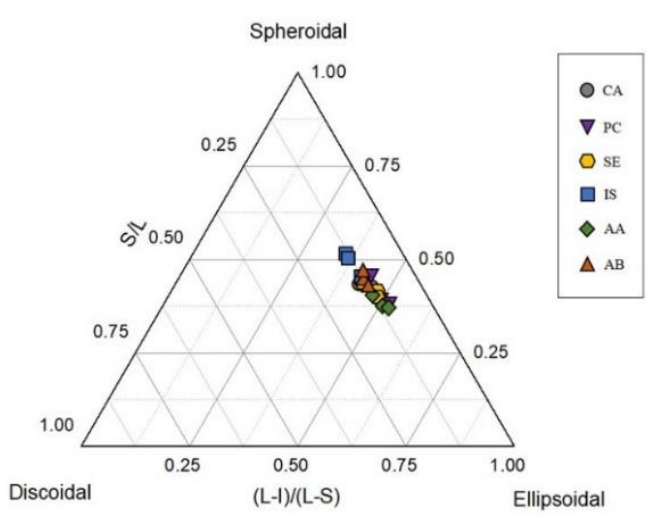

b

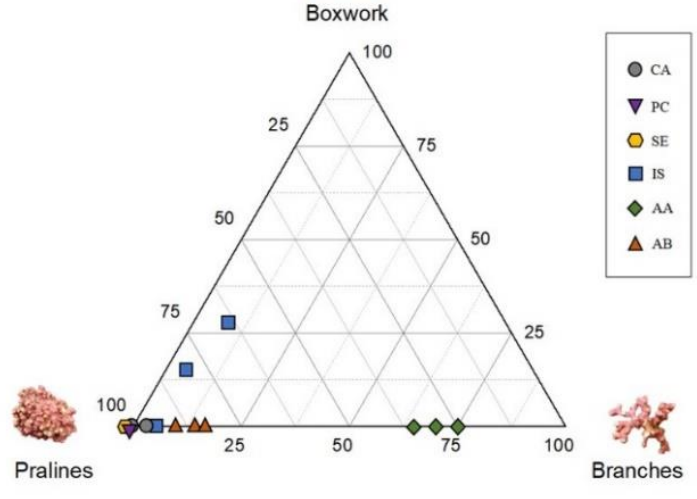

d

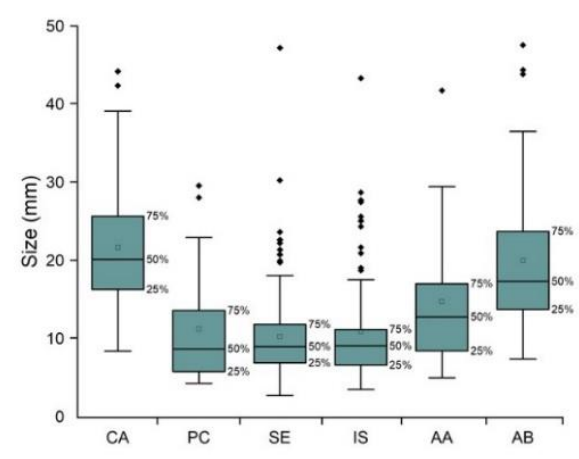

Figure 6. Collected rhodoliths and graphic analyses of their morphology, shape, and size. (a) Detail of collected rhodoliths from MS18-CA1 sampling, from Capri Island, $59 \mathrm{~m}$ depth. (b) Ternary plot of the main morphotypes (i.e., pralines, boxwork rhodoliths, and unattached branches). Each symbol indicates one of the three random samplings collected within each site. (c) Shape classification of rhodoliths using Sneed and Folk's pebble shape diagram [82]. Long (L), intermediate (I), and short (S) axes of rhodoliths. (d) Box plot showing size range of rhodoliths calculated as the volume of an ellipsoid, following [8]; hence, unattached branches were not considered for size measurements. $n=120$, except Acciaroli A, where $n=45$. CA, Capri; PC, Punta Campanella; SE, Secchitiello; IS, Ischia; AA, Acciaroli A; AB, Acciaroli B. 


\subsection{Taxonomic Composition of Coralline Algae}

Most of the rhodoliths observed during the sorting were monospecific, although some oligospecific samples occurred (i.e., boxwork rhodoliths). Thirteen CA taxa were identified, 10 of which at the species level: Lithophyllum racemus (Lamarck) Foslie (Figure 7a,b), Lithophyllum sp., Lithothamnion corallioides (P.Crouan and H.Crouan) P.Crouan and H.Crouan, Lithothamnion crispatum Hauck, Lithothamnion minervae Basso (Figure 7c,d), Lithothamnion sonderi Hauck, Lithothamnion valens Foslie, Lithothamnion spp., Mesophyllum sp., Neogoniolithon hauckii (Rothpletz) R.A.Townsend Huisman (ex Neogoniolithon mamillosum), Phymatolithon calcareum (Pallas) W.H.Adey and D.L.McKibbin ex Woelkering and L.M.Irvine (Figure 7e,f), Spongites fruticulosus Kützing (Figure 7g,h), and Titanoderma pustulatum (J.V.Lamouroux) Nägeli.
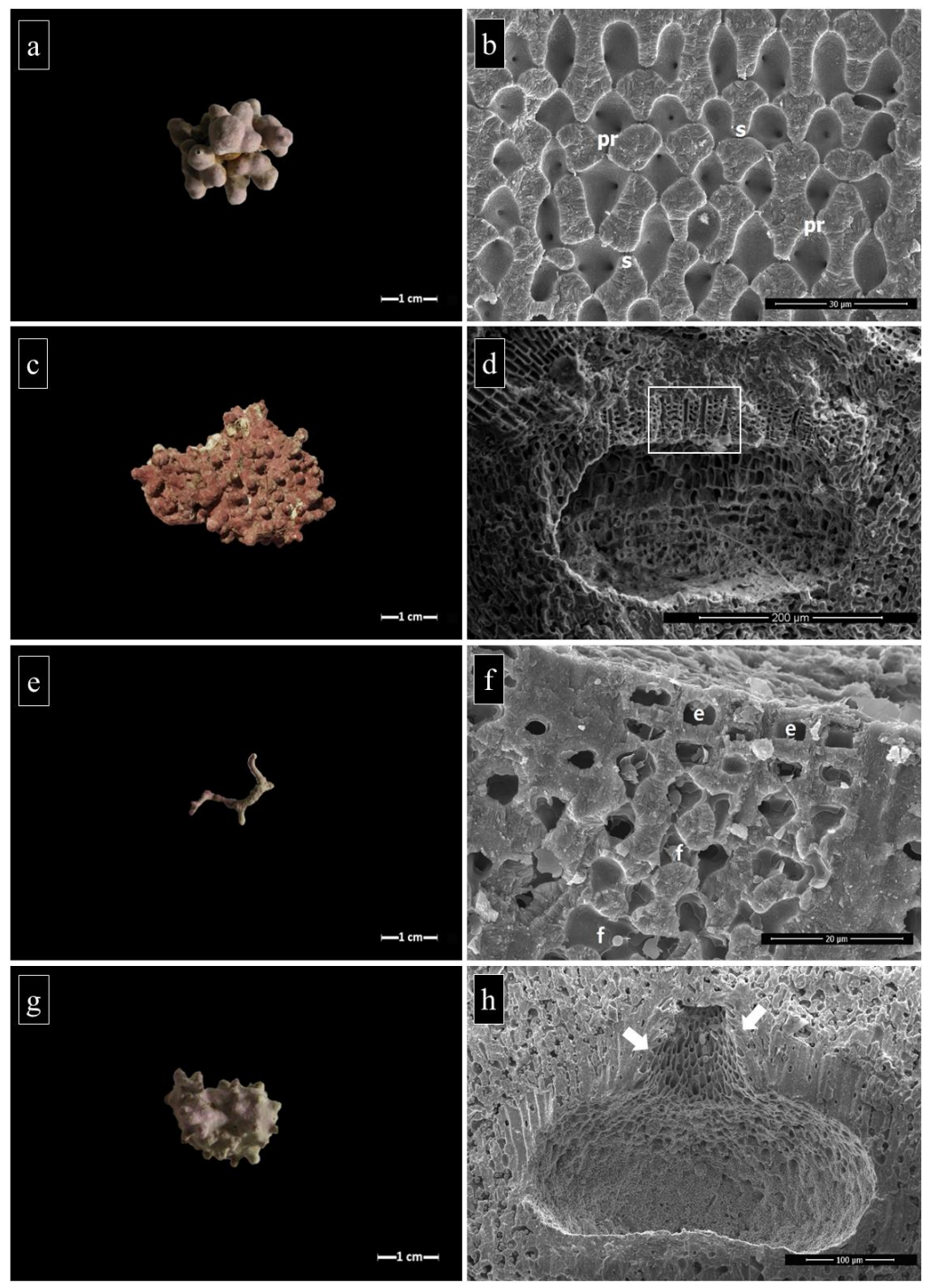

Figure 7. Examples of rhodolith specimens' morphology and SEM images of their inner structure. (a) Fruticose rhodolith of Lithophyllum racemus from Ischia (specimen IS-12). (b) Perithallus of L. racemus (AB-12). Note the primary (pr) and secondary (s) pit connections. (c) Warty rhodolith of Lithothamnion minervae from Capri (specimen CA-33). (d) Multiporate conceptacle of L. minervae (CA-33). Note the pore canals (rectangle). (e) Unattached branch of Phymatolithon calcareum from Acciaroli B (specimen AB-03). (f) Epithallus and perithallus of P. calcareum (AB-03), with dome-shaped epithallial cells (e) and cell fusions (f). (g) Warty rhodolith of Spongites fruticulosus from Acciaroli B (specimen AB-07). (h) Uniporate sporangial conceptacle of $S$. fruticulosus (AB-07). Note the cells protruding laterally into the pore canal (arrows). 
Sites were characterized by a high diversity of CA, ranging from a minimum of 6 CA taxa at Punta Campanella to a maximum of 12 at Capri, Ischia, and Acciaroli B (Figure 8). Lithothamnion minervae was the most abundant species at each site (23-38\%), except at Acciaroli A (15\%), where the most abundant was L. corallioides (69\%).

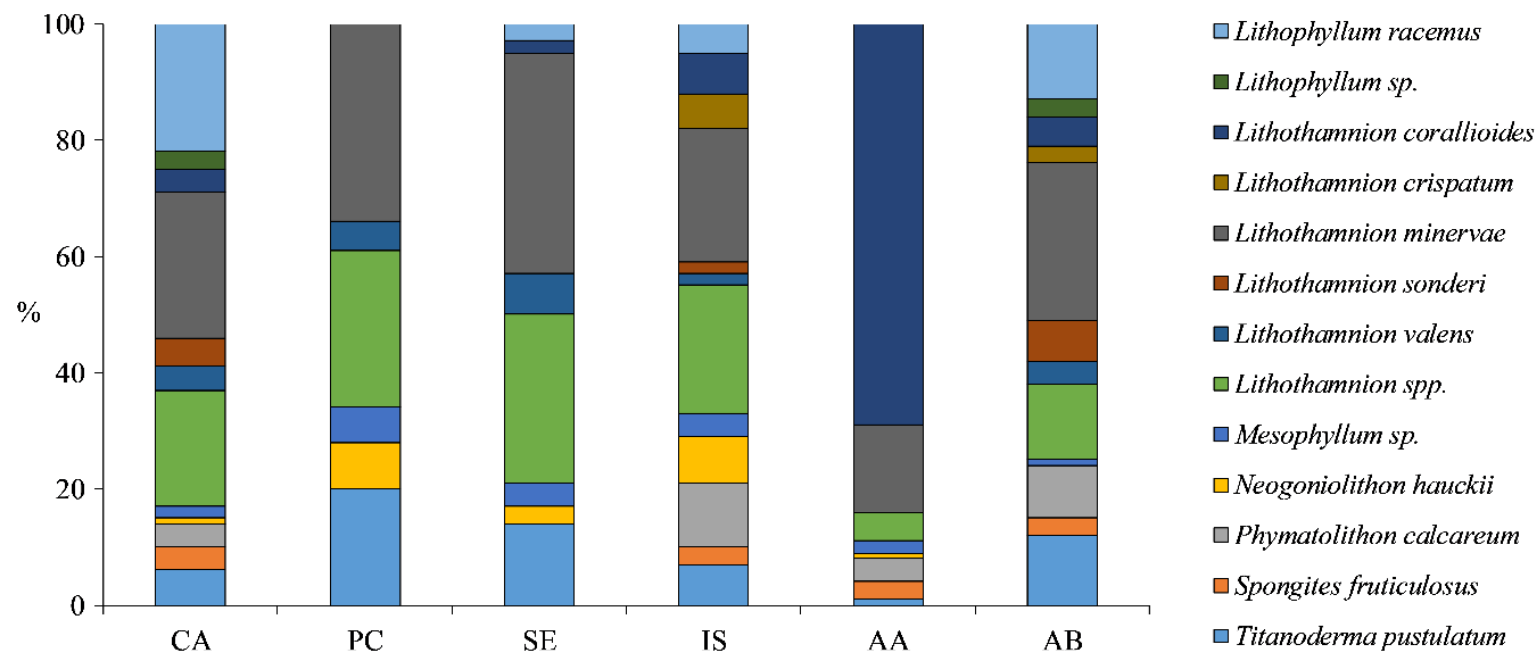

Figure 8. Coverage (\%) of CA taxa at each site. CA, Capri; PC, Punta Campanella; SE, Secchitiello; IS, Ischia; AA, Acciaroli A; AB, Acciaroli B.

\section{Discussion}

\subsection{Characterization of Rhodolith Beds}

A spatial variability of rhodolith covers was observed within the different sites along the ROV video-routes. Spatial heterogeneity, with high cover of rhodoliths interspersed with patches of sediments, has been already reported for deep Mediterranean RBs and seems to be mainly related to seafloor morphology and/or bottom currents $[9,72,86]$.

RBs were found in Capri, Ischia, and Cilento with more than $10 \%$ of the mobile substratum covered by live rhodoliths [2]. Secchitiello and Punta Campanella cannot be considered as proper RBs, since they were mostly characterized by sparse rhodoliths (mean cover $<10 \%$ ). However, these sites showed higher local rhodolith covers $(>10 \%)$ often associated with small accumulation patches and ripple marks, which indicate water motion over the sea floor $[1,51]$.

The bathymetric range of the investigated RBs well compares with other Mediterranean beds, which mainly occur at 30-75 m of depth [1,4]. Rhodolith cover was lower at deeper sites $(60-79 \mathrm{~m})$, compared to the shallower ones $(40-59 \mathrm{~m})$, probably because of light irradiance reduction with depth. Higher rhodolith covers were also detected in concurrence with coarser sediments. This could be related to the presence of suitable sediments (e.g., gravel) for algal spore settlement and RBs development $[1,2,7,67,87]$. Pralines were the prevalent morphotype in almost all sites (except at Acciaroli A), suggesting the presence of high water energy $[2,9,10,88,89]$.

We report the occurrence of a RB off the Capri Island, characterized by the highest rhodolith cover $(>65 \%)$ compared to the other sites, with a low percentage of dead thalli $(16 \%)$ suggesting a good status of the bed. The high cover of rhodoliths might be explained by the abundance of coarse sediments as suitable substrate for CA settlement $[7,10]$.

Acciaroli A was characterized by the prevalence of unattached branches, despite being mostly dead $(76 \%)$ and fragmented. The presence of beds offshore the Cilento peninsula was already reported on submerged terraces between 42 to $52 \mathrm{~m}$ [72], mainly composed by a superficial layer of Lithothamnion corallioides, over a thick dead and sub-fossil rhodolith deposit. At Acciaroli B, the image analysis showed a lower cover of dead thalli (14\%) compared to the live ones. Moreover, although unattached 
branches were observed, pralines were the most abundant morphotype in all the examined video frames. These two sites are most likely part of a unique and wide RB off the Cilento coast, as suggested by SSS data, structured by different rhodolith morphotypes and composed by a healthy "live" part (i.e., the Acciaroli B site) and a "dead" (or fossil) part (i.e., the Acciaroli A site).

An extended area with rhodoliths off the Ischia Island has already been described by [69,70]. They described a 1-mile-long RB located off Ischia between 50 and $65 \mathrm{~m}$ depth, characterized by all the three rhodolith morphotypes, with a predominance of unattached branches of Phymatolithon calcareum and Lithothamnion corallioides. According to these previous studies, we also found in our investigation site all the three morphotypes, although the unattached branches cover was very low $(<10 \%)$ and P. calcareum and L. corallioides were not predominant. Moreover, despite it is common for live RBs to be accompanied by a variable quantity of dead rhodoliths and their fragments [90], we observed a high percentage of dead thalli $(26 \%)$. This finding was not reported in previous studies for Ischia [69,70], and we hypothesize that it could be related to the high fraction of fine sediments observed, which might have caused burial phenomena $[4,67,91]$. However, further investigations would be necessary to evaluate the entity and the possible progression of this algal mortality and its causes.

\subsection{Rhodolith Morphology}

The investigated RBs were similar with each other and with other deep RBs of the Mediterranean Sea [9,10,86,92], characterized by the pralines' facies, as described by Pérès and Picard [93]. CA growth-forms ranged from encrusting/warty to lumpy/fruticose, with several protuberances and branches degrees, mainly depending on the CA species composing the rhodolith [10].

Surface currents within the Gulf of Naples have been deeply investigated [94-99], and there are several models describing their dynamics within the Campania coastal system [100-102]. However, macroscale hydrodynamic measurements at the sea-bottom lack for this area, and hydrodynamic models have limitations in simulating the near-bottom currents due to boundary conditions for numerical resolution. However, rhodoliths can represent, to some extent, a proxy of bottom currents [67]. The spheroidal to ellipsoidal shape of the rhodoliths analysed in this study and the lack of discoidal shapes seem to suggest an equilibrium between a regular frequency of overturning associated with moderate/high water energy, which assures the homogeneous growth of the thallus $[8,10,67,87,103]$. Moreover, the reduced sizes of the rhodoliths composing the Campania beds (i.e., from $21.8 \mathrm{~mm} \pm 8.5$ in Capri to $10.6 \mathrm{~mm} \pm 6.1$ in Secchitiello), according to literature $[2,10,88,89]$, seem to support the presence of an elevated water energy in all sites.

\subsection{Taxonomic Composition of Coralline Algae}

This study provided a first picture of the CA diversity characterizing deep RBs off the Campania coast. The beds characterized by the highest number of CA were Capri, Ischia, and Acciaroli B, with 12 taxa each. The genus Lithothamnion was the most abundant, representing more than $50 \%$ of the total abundance of taxa in each site. L. minervae was the dominant species at each site (23-38\%), except at Acciaroli A (15\%) that was mostly composed by unattached branches of L. corallioides (69\%). At all sites, except Punta Campanella and Secchitiello, we found both species, P. calcareum and L. corallioides, protected by the Habitats Directive (92/43/EEC). These results confirm the studies on Mediterranean RBs that report a high CA species diversity [9,53,70-72,86,104-110], highlighting the elevated scientific and ecological value of these remote biodiversity hot spots in the Mediterranean Sea.

\section{Conclusions}

This work provides new insights at large scale on deep Mediterranean RBs distribution and composition off the Campania coast (eastern Tyrrhenian Sea). The occurrence of a new RB offshore Capri Island, characterized by the highest rhodolith cover $(>65 \%)$ compared to the other studied sites, is reported. The high rhodoliths' cover might be related to the co-occurrence of coarse sediments and shallow depth. Small pralines (ca. $2 \mathrm{~cm}$ ) dominated all the studied RBs, except at Acciaroli A, that was 
mostly composed by dead fragments of unattached branches. Ischia RB was also characterized by a conspicuous cover of dead rhodoliths. The collected rhodoliths were spheroidal to ellipsoidal in all sites, probably indicating a moderate/high hydrodynamism. Growth-forms varied from encrusting/warty to fruticose/lumpy, mainly related to the CA species composing the rhodoliths. CA identification highlighted a high taxonomic diversity (i.e., 13 taxa).

The investigated RBs are particularly valuable since the two species Phymatolithon calcareum and Lithothamnion corallioides, included and protected by the Habitats Directive (92/43/EEC), have been detected in all RBs. This study supports the ecological value of these highly biodiverse yet poorly explored deep macroalgal communities and represents a baseline for their future management and conservation.

Author Contributions: Investigation, F.R., S.K., and A.C.; methodology, F.F., L.A., L.D., and V.R.; writing-original draft, F.R.; writing—review and editing, A.F.; project administration and funding acquisition, G.F.R.; supervision, G.F.R., R.S. and A.F. All authors have read and agreed to the published version of the manuscript.

Funding: This work was financed and supported by the National Inter-University Consortium for Marine Sciences (CoNISMa), within the Marine Strategy Framework Directive (MSFD-2008/56/EC) for the monitoring of rhodolith beds.

Acknowledgments: We would like to thank the head of the sea section of ARPA Campania Lucio De Maio, the ARPAC crew members, and the ROV pilots and technicians of navigation informatics system of Subonica for field activities and data acquisition. We are indebted to Cristina Del Barone (National Research Council) for the help with SEM image acquisition.

Conflicts of Interest: The authors declare no conflict of interest.

\section{References}

1. Basso, D.; Babbini, L.; Kaleb, S.; Bracchi, V.; Falace, A. Monitoring deep Mediterranean rhodolith beds. Aquat. Conserv. 2016, 26, 549-561. [CrossRef]

2. Bosence, D.W.J. The occurrence and ecology of recent rhodoliths (rhodoids, rhodolites). In Classification of Coated Grains; Peryt, T.M., Ed.; Springer-Verlag: Berlin, Germany, 1983; pp. 225-242.

3. Steller, D.L.; Riosmena-Rodriguez, R.; Foster, M.S.; Roberts, C.A. Rhodolith bed diversity in the Gulf of California: The importance of rhodolith structure and consequences of disturbance. Aquat. Conserv. 2003, 13, S5-S20. [CrossRef]

4. Foster, M.S.; Filho, G.M.A.; Kamenos, K.A.; Riosmena-Rodríguez, R.; Steller, D.L. Rhodoliths and rhodolith beds. In Research and Discoveries: The Revolution of Science Through SCUBA; American Academy of Underwater Sciences: Mobile, AL, USA, 2013; pp. 143-155.

5. Scoffin, T.P.; Stoddart, D.R.; Tudhope, A.W.; Woodroffe, C. Rhodoliths and coralliths of Muri Lagoon, Rarotonga, Cook Islands. Coral Reefs 1985, 4, 71-80. [CrossRef]

6. Amado-Filho, G.M.; Moura, R.L.; Bastos, A.C.; Salgado, L.T.; Sumida, P.Y.; Guth, A.Z.; Francini-Filho, R.B.; Pereira-Filho, G.H.; Abrantes, D.P.; Poliana, S.; et al. Rhodolith beds are major $\mathrm{CaCO}_{3}$ bio-factories in the tropical South West Atlantic. PLoS ONE 2012, 7, e35171. [CrossRef]

7. Bosence, D.W.J. The morphology and ecology of a mound-building coralline alga (Neogoniolithon strictum) from the Florida Keys. Paleontology 1985, 28, 189-206.

8. Bosence, D.W.J. Ecological studies on two unattached coralline algae from western Ireland. Palaeontology 1976, 19, 365-395.

9. Bracchi, V.A.; Lorenzo, A.; Marchese, F.; Taviani, M.; Cardone, F.; Hajdas, I.; Grande, V.; Prampolini, M.; Caragnano, A.; Corselli, C.; et al. A resilient deep-water rhodolith bed off the Egadi Archipelago (Mediterranean Sea) and its actuopaleontological significance. Alp. Mediterr. Quat. 2019, 32, 1-20.

10. Basso, D. Deep rhodolith distribution in the Pontian Islands, Italy: A model for the paleoecology of a temperate sea. Palaeogeogr. Palaeoclimatol. Palaeoecol. 1998, 137, 173-187. [CrossRef]

11. Sciberras, M.; Rizzo, M.; Mifsud, J.R.; Camilleri, K.; Borg, J.A.; Lanfranco, E.; Schembri, P.J. Habitat structure and biological characteristics of a maerl bed off the northeastern coast of the Maltese Islands (central Mediterranean). Mar. Biodivers. 2009, 39, 251-264. [CrossRef]

12. Freiwald, A. Sedimentological and biological aspects in the formation of branched rhodoliths in northern Norway. Beiträge zur Paläontologie Osterreichs 1995, 20, 7-19. 
13. Teichert, S.; Woelkerling, W.; Rüggeberg, A.; Wisshak, M.; Piepenburg, D.; Meyerhöfer, M.; Form, A.; Freiwald, A. Arctic rhodolith beds and their environmental controls (Spitsbergen, Norway). Facies 2014, 60, 15-37. [CrossRef]

14. Teichert, S.; Woelkerling, W.; Rüggeberg, A.; Wisshak, M.; Piepenburg, D.; Meyerhöfer, M.; Form, A.; Büdenbender, J.; Freiwald, A. Rhodolith beds (Corallinales, Rhodophyta) and their physical and biological environment at $80^{\circ} 31^{\prime} \mathrm{N}$ in Nordkappbukta (Nordaustlandet, Svalbard Archipelago, Norway). Phycologia 2012, 51, 371-390. [CrossRef]

15. Aguilar, R.; Pastor, X.; Torriente, A.; Garcia, S. Deep-sea coralligenous beds observed with ROV on four seamounts in the western Mediterranean. In Proceedings of the 1st Mediterranean Symposium on the Conservation of the Coralligenous and Others Calcareous Bio-Concretions, Tabarka, Tunis, 15-16 January 2009; pp. 147-149.

16. Hinojosa-Arango, G.; Riosmena-Rodríguez, R. Influence of Rhodolith-forming species and growth-form on associated fauna of rhodolith beds in the central-west Gulf of California, México. Mar. Ecol. 2004, 25, 109-127. [CrossRef]

17. Teichert, S. Hollow rhodoliths increase Svalbard's shelf biodiversity. Sci. Rep. 2014, 4, 6972. [CrossRef] [PubMed]

18. Otero-Ferrer, F.; Mannarà, E.; Cosme, M.; Falace, A.; Montiel-Nelson, J.A.; Espino, F.; Haroun, R.; Tuya, F. Early-faunal colonization patterns of discrete habitat units: A case study with rhodolith-associated vagile macrofauna. Estuar. Coast. Mar. Sci. 2019, 218, 9-22. [CrossRef]

19. Grall, J.; Glemarec, M. Biodiversite des fonds de maërl en Bretagne: Approache fonctionnelle et impacts anthropogeniques. Vie Milieu 1997, 47, 339-349.

20. Birkett, D.; Maggs, C.; Dring, M. Maërl, Volume V: An Overview of Dynamic and Sensitivity Characteristics for Conservation Management of Marine SACs; Scottish Association for Marine Science: Oban, UK, 1998.

21. Hall-Spencer, J.M.; Grall, J.; Moore, P.G.; Atkinson, R.J.A. Bivalve fishing and maerl-bed conservation in France and the UK-retrospect and prospect. Aquat. Conserv. 2003, 13, S33-S41. [CrossRef]

22. Jacquotte, R. Etude des fonds de maerl de Méditerranée. Recueil Travaux StationMarine d'Endoume 1962, 26, 141-216.

23. Nicoletti, L.; Paganelli, D.; Gabellini, M. Aspetti Ambientali del Dragaggio di Sabbie Relitte a Fini di Ripascimento: Proposta di un Protocollo di Monitoraggio; ISPRA Istituto Superiore per la Protezione e la Ricerca Ambientale: Rome, Italy, 2006; Volume 5, p. 159.

24. Martin, S.; Gattuso, J.P. Response of Mediterranean coralline algae to ocean acidification and elevated temperature. Glob. Chang. Biol. 2009, 15, 2089-2100. [CrossRef]

25. Foster, M.S. Rhodoliths: Between rocks and soft places. J. Phycol. 2001, 37, 659-667. [CrossRef]

26. Kamenos, N.A.; Moore, P.; Hall-Spencer, J. Substratum heterogeneity of dredged vs un-dredged maerl grounds. J. Mar. Biolog. Assoc. 2003, 83, 411-413. [CrossRef]

27. Blake, C.; Maggs, C.A. Comparative growth rates and internal banding periodicity of maerl species (Corallinales, Rhodophyta) from northern Europe. Phycologia 2003, 42, 606-612. [CrossRef]

28. De Grave, S. The influence of sedimentary heterogeneity on within maërl bed differences in infaunal crustacean community. Estuar. Coast. Shelf Sci. 1999, 49, 153-163. [CrossRef]

29. Hall-Spencer, J.M.; Moore, P.G. Scallop dredging has profound, long-term impacts on maërl habitats. ICES J. Mar. Sci. 2000, 57, 1407-1415. [CrossRef]

30. Bordehore, C.; Borg, J.A.; Lanfranco, E.; Ramos-Esplá, A.; Rizzo, M.; Schembri, P.J. Trawling as a major threat to Mediterranean maerl beds. In Proceedings of the Symposium on marine vegetation, Ajaccio, France, 3-4 October 2000.

31. Bordehore, C.; Ramos-Esplá, A.A.; Riosmena-Rodríguez, R. Comparative study of two maerl beds with different otter trawling history, southeast Iberian Peninsula. Aquat. Conserv. 2003, 13, S43-S54. [CrossRef]

32. Hall-Spencer, J.M.; White, N.; Gillespie, E.; Gillham, K.; Foggo, A. Impact of fish farms on maërl beds in strongly tidal areas. Mar. Ecol. Prog. Ser. 2006, 326, 1-9. [CrossRef]

33. Sanz-Lázaro, C.; Belando, M.D.; Lázaro Marín-Guirao, L.; Navarrete-Mier, F.; Arnaldo, M.A. Relationship between sedimentation rates and benthic impact on Maërl beds derived from fish farming in the Mediterranean. Mar. Environ. Res. 2011, 71, 22-30. [CrossRef]

34. McCoy, S.J.; Ragazzola, F. Skeletal trade-offs in coralline algae in response to ocean acidification. Nat. Clim. Chang. 2014, 4, 719-723. [CrossRef] 
35. Rendina, F.; Bouchet, P.J.; Appolloni, L.; Russo, G.F.; Sandulli, R.; Kolzenburg, R.; Putra, A.; Ragazzola, F. Physiological response of the coralline alga Corallina officinalis L. to both predicted long-term increases in temperature and short-term heatwave events. Mar. Environ. Res. 2019, 150, 104764. [CrossRef] [PubMed]

36. Rindi, F.; Braga, J.; Martin, S.; Peña, V.; Le Gall, L.; Caragnano, A.; Aguirre, J. Coralline algae in a changing Mediterranean Sea: How can we predict their future, if we do not know their present? Front. Mar. Sci. 2019, 6, 723. [CrossRef]

37. Barberá, C.; Bordehore, C.; Borg, J.A.; Glemarec, M.; Grall, J.; Hall-Spencer, J.M.; De la Huz, C.; Lanfranco, E.; Lastra, M.; Moore, P.G.; et al. Conservation and management of northeast Atlantic and Mediterranean maërl beds. Aquat. Conserv. 2003, 13, S65-S76. [CrossRef]

38. Nelson, W. Calcified macroalgae-Critical to coastal ecosystems and vulnerable to change: A review. Mar. Freshwater Res. 2009, 60, 787-801. [CrossRef]

39. Aguado-Giménez; F.; Ruiz-Fernández, J.M. Influence of an experimental fish farm on the spatio-temporal dynamic of a Mediterranean maërl algae community. Mar. Environ. Res 2012, 74, 47-55. [CrossRef] [PubMed]

40. European Communities. Council directive 1992/43/EC Conservation of natural habitats and of wild fauna and flora. Off. J. Eur. Union 1992, L206, 7-50.

41. European Parliament. Council of the European Union Directive 2008/56/EC of the European Parliament and of the Council of 17 June 2008 establishing a framework for Community action in the field of marine environmental policy (Marine Strategy Framework Directive). Off. J. Eur. Union 2008, L164, 19.

42. European Commission. Commission decision of 1 September 2010 on criteria and methodological standards on good environmental status of marine waters. Off. J. Eur. Union 2010, L232, 14.

43. Ballesteros, E. Composición y estructura de los fondos de maërl de Tossa de Mar (Girona, España). Collectanea Botanica 1989, 17, 161-182. [CrossRef]

44. Ballesteros, E. Mediterranean coralligenous assemblages: A synthesis of present knowledge. Oceanogr. Mar. Biol. 2006, 44, 123-195.

45. Templado, J.; Calvo, M.; García-Carrascosa, A.M.; Boisset, F.; Jiménez, J. Flora y Fauna de la Reserva Marina de las Islas Columbretes; Secretaría Gral. Pesca Marítima. $\mathrm{M}^{\circ}$ Agricultura, Pesca y Alimentación: Madrid, Spain; Museo Nacional de Ciencias Naturales: Madrid, Spain; CSIC: Madrid, Spain, 2002; p. 263.

46. Castriota, L.; Gambi, M.C.; Zupo, V.; Sunseri, G. Structure and trophic ecology of a population of Lysidice ninetta (Polychaeta) associated to rhodoliths off the island of Ustica (Southern Tyrrhenian Sea). Biol. Mar. Mediterr. 2003, 10, 517-520.

47. Castriota, L.; Agamennone, F.; Sunseri, G. The mollusc community associated with maerl beds of Ustica Island (Tyrrhenian Sea). Cah. Biol. Mar. 2005, 46, 289-297.

48. Ramos-Esplá, A.A.; Luque, A.A. Los fondos de "maerl". In Pradera y Bosques Marinos de Andalucía; Luque, A.A., Templado, J., Eds.; Consejería de Medio Ambiente, Junta de Andalucía: Sevilla, Spain, 2004; pp. 221-236.

49. Ramos-Esplá, A.A.; Luque, A.A. The Seas of Spain. Maerl Beds: A Fragile Oasis of Marine Life; Ministero del Medio Ambiente y Medio Rural y Marino: Madrid, Spain, 2008; pp. 273-290.

50. Ordines, F.; Massutí, E. Relationships between macro-epibenthic communities and fish on the shelf grounds of the western Mediterranean. Aquat. Conserv. 2009, 19, 370-383. [CrossRef]

51. Barberá, C.; Moranta, J.; Ordines, F.; Ramón, M.; de Mesa, A.; Díaz-Valdés, M.; Grau, A.M.; Massutí, E. Biodiversity and habitat mapping of Menorca Channel (western Mediterranean): Implications for conservation. Biodivers. Conserv. 2012, 21, 701-728. [CrossRef]

52. Cattaneo-Vietti, R.; Bo, M.; Cannas, R.; Cau, A.; Follesa, C.; Meliadò, E.; Russo, G.F.; Sandulli, R.; Bavestrello, G. An overexploited Italian treasure: Past and present distribution and exploitation of the precious red coral Corallium rubrum (L., 1758) (Cnidaria: Anthozoa). Ital. J. Zool. 2016, 83, 443-455. [CrossRef]

53. Basso, D.; Babbini, L.; Ramos-Esplá, A.A.; Salomidi, M. Mediterranean Rhodolith Beds. In Rhodolith/Maërl Beds: A Global Perspective; Riosmena-Rodríguez, R., Nelson, W., Aguirre, J., Eds.; Coastal Research Library; Springer: Cham, Switzerland, 2017; Volume 15.

54. Donnarumma, L.; Sandulli, R.; Appolloni, L.; Di Stefano, F.; Russo, G.F. Morpho-structural and ecological features of a shallow vermetid bioconstruction in the Tyrrhenian Sea (Mediterranean Sea, Italy). J. Sea Res. 2018, 131, 61-68. [CrossRef]

55. Ingrosso, G.; Cecchi, L.; Bertolino, M.; Bevilacqua, S.; Bianchi, C.N.; Bo, M.; Boscari, E.; Cardone, F.; Cattaneo-Vietti, R.; Cau, A.; et al. Mediterranean Bioconstructions Along the Italian Coast. Adv. Mar. Biol. 2018, 79, 61-136. [PubMed] 
56. Basso, D.; Babbini, L.; Kaleb, S.; Falace, A.; Bracchi, V. A protocol for the monitoring of Mediterranean rhodolith beds. In Proceedings of the 2nd Mediterranean Symposium on the Conservation of Coralligenous and other Calcareous Bio-Concretions, Portorož, Slovenia, 29-30 October 2014.

57. Piazzi, L.; Gennaro, P.; Cecchi, E.; Serena, F. Improvement of the ESCA index for the evaluation of ecological quality of coralligenous habitat under the European Framework Directives. Mediterr. Mar. Sci. 2015, 16, 419-426. [CrossRef]

58. Ferrigno, F.; Appolloni, L.; Russo, G.F.; Sandulli, R. Impact of fishing activities on different coralligenous assemblages of Gulf of Naples (Italy). J. Mar. Biol. Assoc. U.K. 2018, 98, 41-50. [CrossRef]

59. Ferrigno, F.; Appolloni, L.; Rendina, F.; Donnarumma, L.; Russo, G.F.; Sandulli, R. Red coral (Corallium rubrum) populations and coralligenous characterization within "Regno di Nettuno MPA" (Tyrrhenian Sea, Italy). Eur. Zool. J. 2020, 87, 203-213. [CrossRef]

60. Chimienti, G.; Angeletti, L.; Rizzo, L.; Tursi, A.; Mastrototaro, F. ROV vs trawling approaches in the study of benthic communities: The case of Pennatula rubra (Cnidaria: Pennatulacea). J. Mar. Biolog. Assoc. 2018, 98, 1859-1869. [CrossRef]

61. Chimienti, G.; De Padova, D.; Mossa, M.; Mastrototaro, F. A mesophotic black coral forest in the Adriatic Sea. Sci. Rep. 2020, 10, 1-15. [CrossRef]

62. Bo, M.; Bava, S.; Canese, S.; Angiolillo, M.; Cattaneo-Vietti, R.; Bavestrello, G. Fishing impact on deep Mediterranean rocky habitats as revealed by ROV investigation. Biol. Conserv. 2014, 171, 167-176. [CrossRef]

63. Ferrigno, F.; Russo, G.F.; Sandulli, R. Coralligenous Bioconstructions Quality Index (CBQI): A synthetic indicator to assess the status of different types of coralligenous habitats. Ecol. Indic. 2017, 82, 271-279. [CrossRef]

64. Rendina, F.; Ferrigno, F.; Appolloni, L.; Donnarumma, L.; Sandulli, R.; Russo, G.F. Anthropic pressure due to lost fishing gears and marine litter on different rhodolith beds off the Campania coast. (Tyrrhenian Sea, Italy). Ecol. Quest. 2020, in press.

65. Hernandez-Kantun, J.J.; Hall-Spencer, J.M.; Grall, J.; Adey, W.; Rindi, F.; Maggs, C.A.; Bárbara, I.; Peña, V. North Atlantic rhodolith beds. In Rhodolith/Maërl Beds: A Global Perspective; Riosmena-Rodríguez, R., Nelson, W., Aguirre, J., Eds.; Coastal Research Library; Springer: Cham, Switzerland, 2017; Volume 15.

66. Bosellini, A.; Ginsburg, R. Form and internal structure of recent algal nodules (Rhodolites) from Bermuda. J. Geol. 1971, 79, 669-682. [CrossRef]

67. Marrack, E.C. The relationship between water motion and living rhodolith beds in the southwestern Gulf of California, Mexico. Palaios 1999, 159-171. [CrossRef]

68. Riosmena-Rodríguez, R. Natural History of Rhodolith/ Maërl Beds: Their Role in Near-Shore Biodiversity and Management. In Rhodolith/Maërl Beds: A Global Perspective; Riosmena-Rodríguez, R., Nelson, W., Aguirre, J., Eds.; Coastal Research Library; Springer: Cham, Switzerland, 2017; pp. 3-26.

69. Babbini, L.; Bressan, G.; Massa-Gallucci, A.; Buia, M.C.; Gambi, M.C. Segnalazione di una faciesa mäerl (Rhodophyta, Corallinales) lungo le coste dell'isola d'Ischia. Biol. Mar. Mediterr. 2006, 13, 548-552.

70. Gambi, M.C.; Buia, M.C.; Massa-Gallucci, A.; Cigliano, M.; Lattanzi, L.; Patti, F.P. The "pink mile": Benthic assemblages of rhodolith and mäerl beds (Corallinales) off the Island of Ischia (Tyrrhenian Sea). In Proceedings of the 1st Mediterranean Symposium on the Conservation of the Coralligenous and Others Calcareous Bio-Concretions, Tabarka, Tunis, 15-16 January 2009.

71. Toscano, F.; Vigliotti, M.; Simone, L. Variety of coralline algal deposits (rhodalgal facies) from the Bays of Naples and Pozzuoli (northern Tyrrhenian Sea, Italy). Geol. Soc. Spec. Publ. 2006, 255, 85-94. [CrossRef]

72. Savini, A.; Basso, D.; Bracchi, V.A.; Corselli, C.; Pennetta, M. Maerl-bed mapping and carbonate quantification on submerged terraces offshore the Cilento peninsula (Tyrrhenian Sea, Italy). Geodiversitas 2012, 34, 77-98. [CrossRef]

73. Ware, S.J.; Kenny, A.J. Guidelines for the Conduct of Benthic Studies at Marine Aggregate Extraction Sites, 2nd ed.; Marine Aggregate Levy Sustainability Fund, MALSF: Lowestoft, UK, 2011; p. 80.

74. Jones, D.L.; Langman, R.; Reach, I.; Gribble, J.; Griffiths, N. Using multibeam and sidescan sonar to monitor aggregate dredging. In Seafloor Mapping along Continental Shelves; Springer: Cham, Switzerland, 2016; pp. 245-259.

75. Ministero Dell'ambiente e della Tutela del Territorio e del Mare. Programmi di Monitoraggio per la Strategia Marina Art. 11, D.lgs. 190/2010. Scheda Metodologica Modulo 8 Habitat Fondi a Maerl/Rodoliti; Ministero dell'Ambiente e della Tutela del Territorio e del Mare: Rome, Italy, 2016. 
76. Peña, V.; Barbara, I. Seasonal patterns in the mäerl community of shallow European Atlantic beds and their use as a baseline for monitoring studies. Eur. J. Phycol. 2010, 45, 327-342. [CrossRef]

77. Terlizzi, A.; Anderson, M.J.; Fraschetti, S.; Benedetti-Cecchi, L. Scales of spatial variation in Mediterranean subtidal sessile assemblages at different depths. Mar. Ecol. Prog. Ser. 2007, 332, 25-39. [CrossRef]

78. Guidetti, P.; Baiata, P.; Ballesteros, E.; Di Franco, A.; Hereu, B.; Macpherson, E.; Micheli, F.; Pais, A.; Panzalis, P.; Rosenberg, A.A.; et al. Large-scale assessment of Mediterranean marine protected areas effects on fish assemblages. PLoS ONE 2014, 9, e91841. [CrossRef] [PubMed]

79. Anderson, M. A new method for non-parametric multivariate analysis of variance. Austral. Ecol. 2001, 26, 32-46.

80. Hammer, Ø.; Harper, D.A.T.; Ryan, P.D. Past: Palaeontological statistics software package for education and data analysis. Palaeontol. Electron. 2001, 4, 1-9.

81. Bosence, D.W.J. Description and Classification of Rhodoliths (Rhodoids, Rhodolites). In Coated Grains; Peryt, T.M., Ed.; Springer-Verlag: Berlin, Germany, 1983; pp. 217-224.

82. Sneed, E.D.; Folk, R.L. Pebbles in the lower Colorado River, Texas, a study of particle morphogenesis. J. Geol. 1958, 66, 114-150. [CrossRef]

83. Kaleb, S.; Alongi, G.; Falace, A. Coralline algae preparation for scanning electron microscopy and optical microscopy. In Protocols for Macroalgae Research; Charrier, B., Wichard, T., Reddy, C.R.K., Eds.; CRC Press, Taylor and Franciss Group: Boca Raton, FL, USA, 2018; pp. 413-429.

84. Guiry, M.D.; Guiry, G.M.; AlgaeBase. World-Wide Electronic Publication. National University of Ireland, Galway. 2020. Available online: http://www.algaebase.org (accessed on 20 June 2020).

85. Hedley, J. VidAna 1.0 Software for Cover Analysis from Video Footage or Still Images; Marine Spatial Ecology Lab, School of Biological \& Chemical Sciences, University of Exeter: Exeter, UK, 2003.

86. Ingrassia, M.; Martorelli, E.; Sañé, E.; Falese, F.G.; Bosman, A.; Bonifazi, A.; Argenti, L.; Chiocci, F.L. Coralline algae on hard and soft substrata of a temperate mixed siliciclastic-carbonatic platform: Sensitive assemblages in the Zannone area (western Pontine Archipelago; Tyrrhenian Sea). Mar. Environ. Res. 2019, 147, 1-12. [CrossRef]

87. Adey, W.H.; MacIntyre, I.G. Crustose coralline algae: A re-evaluation in the geological sciences. Geol. Soc. Am. Bull. 1973, 84, 883-904. [CrossRef]

88. Amado-Filho, G.M.; Maneveldt, G.; Manson, R.C.C.; Marina Rosa, B.V.; Pacheco, M.R.; Guimarães, S.M.P.D. Structure of rhodolith beds from 4 to 55 meters deep along the southern coast of Espírito Santo state, Brazil. Cienc. Mar. 2007, 33, 399-410. [CrossRef]

89. Gagnon, P.; Matheson, K.; Stapleton, M. Variation in rhodolith morphology and biogenic potential of newly discovered rhodolith bed in Newfoundland and Labrador (Canada). Bot. Mar. 2012, 55, 85-99. [CrossRef]

90. Bracchi, V.A.; Basso, D. The contribution of calcareous algae to the biogenic carbonates of the continental shelf: Pontian Islands, Tyrrhenian Sea, Italy. Geodiversitas 2012, 34, 61-77. [CrossRef]

91. Steneck, R.S. The ecology of coralline algal crusts: Convergent patterns and adaptive strategies. Ann. Rev. Ecol. Syst. 1986, 17, 273-303. [CrossRef]

92. Sañé, E.; Chiocci, F.L.; Basso, D.; Martorelli, E. Environmental factors controlling the distribution of rhodoliths: An integrated study based on seafloor sampling, ROV and side scan sonar data, offshore the W-Pontine Archipelago. Cont. Shelf Res. 2016, 129, 10-22. [CrossRef]

93. Pérès, J.M.; Picard, J. Nouveau manuel de bionomie benthique de la Mer Méditerranée. Rec. Trav. St. Mar. Endoume 1964, 31, 5-137.

94. Menna, M.; Mercatini, A.; Uttieri, M.; Buonocore, B.; Zambianchi, E. Wintertime transport processes in the Gulf of Naples investigated by HF radar measurements of surface currents. Il Nuovo Cimento C 2007, 30, 605-622.

95. Uttieri, M.; Cianelli, D.; Nardelli, B.B.; Buonocore, B.; Falco, P.; Colella, S.; Zambianchi, E. Multiplatform observation of the surface circulation in the Gulf of Naples (Southern Tyrrhenian Sea). Ocean Dyn. 2011, 61, 779-796. [CrossRef]

96. Cianelli, D.; Falco, P.; Iermano, I.; Mozzillo, P.; Uttieri, M.; Buonocore, B.; Zambardino, G.; Zambianchi, E. Inshore/offshore water exchange in the Gulf of Naples. J. Mar. Syst. 2015, 145, 37-52. [CrossRef]

97. Aulicino, G.; Cotroneo, Y.; Lacava, T.; Sileo, G.; Fusco, G.; Carlon, R.; Budillon, G. Results of the first Wave Glider experiment in the southern Tyrrhenian Sea. Adv. Oceanogr. Limnol. 2016, 7. [CrossRef] 
98. Falco, P.; Buonocore, B.; Cianelli, D.; De Luca, L.; Giordano, A.; Iermano, I.; Kalampokis, A.; Saviano, S.; Uttieri, M.; Zambardino, G.; et al. Dynamics and sea state in the Gulf of Naples: Potential use of high-frequency radar data in an operational oceanographic context. J. Oper. Oceanogr. 2016, 9, s33-s45. [CrossRef]

99. Castagno, P.; de Ruggiero, P.; Pierini, S.; Zambianchi, E.; De Alteris, A.; De Stefano, M.; Budillon, G. Hydrographic and dynamical characterisation of the Bagnoli-Coroglio Bay (Gulf of Naples, Tyrrhenian Sea). Chem. Ecol. 2020, 36, 598-618. [CrossRef]

100. De Ruggiero, P.; Napolitano, E.; Iacono, R.; Pierini, S. A high-resolution modelling study of the circulation along the Campania coastal system, with a special focus on the Gulf of Naples. Cont. Shelf Res. 2016, 122, 85-101. [CrossRef]

101. De Ruggiero, P.; Napolitano, E.; Iacono, R.; Pierini, S.; Spezie, G. A baroclinic coastal trapped wave event in the Gulf of Naples (Tyrrhenian Sea). Ocean Dyn. 2018, 68, 1683-1694. [CrossRef]

102. De Ruggiero, P.; Esposito, G.; Napolitano, E.; Iacono, R.; Pierini, S.; Zambianchi, E. Modelling the marine circulation of the Campania coastal system (Tyrrhenian Sea) for the year 2016: Analysis of the dynamics. J. Mar. Syst. 2020, 210, 103388. [CrossRef]

103. Caragnano, A.; Basso, D.; Rodondi, G. Growth rates and ecology of coralline rhodoliths from the Ras Ghamila back reef lagoon, Red Sea. Mar. Ecol. 2016, 37, 713-726. [CrossRef]

104. Lanfranco, E.; Rizzo, M.; Hall-Spencer, J.; Borg, J.A.; Schembri, P.J. Maerl-forming coralline algae and associated phytobenthos from the Maltese Islands. Central Mediterr. Nat. 1999, 3, 1-6.

105. Basso, D. Study of living calcareous algae by a paleontological approach: The non-geniculate Corallinaceae (Rhodophyta) of the soft bottoms of the Tyrrhenian Sea (Western Mediterranean). The genera Phymatolithon Foslie and Mesophyllum Lemoine. Riv. It. Paleont. Strat. 1994, 100, 575-596.

106. Basso, D. Living calcareous algae by a paleontological approach: The genus Lithothamnion Heydrich nom. cons. from the soft bottoms of the Tyrrhenian Sea (Mediterranean). Riv. It. Paleont. Strat. 1995, 101. [CrossRef]

107. Basso, D.; Rodondi, G. A Mediterranean population of Spongites fruticulosus (Rhodophyta, Corallinales), the type species of Spongites, and the taxonomic status of S. stalactitica and S. racemosa. Phycologia 2006, 45, 403-416. [CrossRef]

108. Basso, D.; Fravega, P.; Vannucci, G. Fossil and living corallinaceans related to the mediterranean endemic species Lithophyllum racemus (Lamarck) Foslie. Facies 1996, 35, 275. [CrossRef]

109. Bressan, G.; Babbini, L. Biodiversità marina delle coste italiane: Corallinales del Mar Mediterraneo. Guida alla determinazione. Biol. Mar. Mediterr. 2003, 10, 1-237.

110. Falace, A.; Kaleb, S.; Agnesi, S.; Annunziatellis, A.; Salvati, E.; Tunesi, L. Macroalgal composition of rhodolith beds in a pilot area of the Tuscan archipelago (Tyrrhenian Sea): Primary elements to evaluate the degree of conservation of this habitat. In Second Mediterranean Symposium on the conservation of Coralligenous and other Calcareous Bio-Concretions; Bouafif, C., Langar, H., Ouerghi, A., Eds.; RAC/SPA: Tunis, Tunisia, 2014; pp. 213-214.

(C) 2020 by the authors. Licensee MDPI, Basel, Switzerland. This article is an open access article distributed under the terms and conditions of the Creative Commons Attribution (CC BY) license (http://creativecommons.org/licenses/by/4.0/). 